\title{
Effect of Postharvest Defoliation on Carbon and Nitrogen Resources of High-Yielding Sauvignon blanc Grapevines
}

\author{
Marc M. Greven, ${ }^{1 *}$ Sue M. Neal, ${ }^{1}$ D. Stuart Tustin, ${ }^{2}$ Helen Boldingh,${ }^{3}$ \\ Jeff Bennett, ${ }^{1}$ and Maria Carmo Vasconcelos ${ }^{4}$
}

\begin{abstract}
We quantified the importance of postharvest carbohydrate assimilation and nitrogen availability to replenish vine reserves, over and above maintaining optimal growth, productivity, and fruit quality of high-yielding, vigorous Sauvignon blanc grapevines. To create different carbohydrate $(\mathrm{CHO})$ and nitrogen $(\mathrm{N})$ reserve concentrations, our factorial-design trial consisted of a postharvest defoliation treatment overlaid with a pruning treatment in which 48 or 72 nodes were retained on four- or six-cane vertical shoot positioned vines, respectively. In defoliation (Defol) vines, all leaves were removed immediately after fruit harvest, while foliated vines (Fol) went through normal senescence. From just after ectodormancy in 2008, samples of root and trunk tissue were taken throughout the years for $\mathrm{CHO}$ and $\mathrm{N}$ analyses and results were compared with annual yield data. Both defoliation and node number treatments reduced vine growth and yield. Additionally, differences in $\mathrm{CHO}$ and $\mathrm{N}$ of the permanent structure were found. Depleted winter reserves in trunk and root were replenished during the next growth cycle, suggesting that grapevine $\mathrm{N}$ and $\mathrm{CHO}$ partitioning favor survival of the permanent structure over increasing vine size and yield. However, after two consecutive years of defoliation, the cumulative effects of smaller, less fruitful canes from year one and reduced carbohydrates from the subsequent year reduced both yield and vegetative growth in the third growing season. Therefore, even the short-lived postharvest canopy in cool climates contributes to the vine $\mathrm{CHO}$ economy. Defoliation or excessive crop loads affected carbohydrate reserves in vines, but only after several consecutive years of low recharge; this manifested iteself in lower yields and poorer vegetative growth.
\end{abstract}

Key words: carbohydrate, crop load, nitrogen, postharvest defoliation, reserves

Carbohydrates $(\mathrm{CHO})$ are the direct products of photosynthesis and are therefore the primary energy storage compounds found in plants and the starting material from which most organic compounds are synthesized (Kozlowski and Pallardy 1997). CHO accumulation in vine reserve organs depends on the photosynthesis rate and on $\mathrm{CHO}$ partitioning among shoot, root, and fruit growth and storage (Howell 2001). In grapevines, the greatest proportion of total seasonally assimilated carbon is incorporated into structural cellulose compounds in roots,

\footnotetext{
${ }^{1}$ New Zealand Institute for Plant and Food Research, Ltd., PO Box 845, Blenheim 7240, New Zealand; ${ }^{2}$ New Zealand Institute for Plant and Food Research, Ltd., Private Bag 1401, Havelock North 4157, New Zealand; ${ }^{3}$ New Zealand Institute for Plant and Food Research, Ltd., Private Bag 3230, Waikato Mail Centre, Hamilton 3240, New Zealand; and ${ }^{4}$ Eastern Institute of Technology, Private Bag 120, Hawke's Bay Mail Centre, Napier 4142, New Zealand.

*Corresponding author (marc.greven@plantandfood.co.nz; tel: +64 3 9844316; fax: +64 3 9844311)

Acknowledgments: This research was funded by New Zealand Winegrowers and was aligned to the Designer Grapevines program funded by the New Zealand Foundation for Research Science and Technology, contract number C06X0707. The authors would also like to acknowledge the Marlborough Research Centre for the use of the Rowley Crescent vineyard; PFR staff at the Marlborough Research Centre for field and laboratory technical assistance; Chen Goh of PFR, Ruakura, for the CHO analysis; and Delphine Goffette and Tremain Hatch, overseas intern students, who helped on this project.

Manuscript submitted Aug 2015, revised Jan 2016, Mar 2016, accepted Mar 2016

Copyright $(C 2016$ by the American Society for Enology and Viticulture. All rights reserved.
}

doi: 10.5344/ajev.2016.15081 stems, and shoots (Winkler and Williams 1938). These complex structural CHOs cannot be remobilized, as plants lack the enzymes to degrade cellulose (Kozlowski and Pallardy 1997). Resumption of vegetative and reproductive growth in the new season depends on carbon stored as non-structural $\mathrm{CHO}$ reserves, mainly in the form of starch (Stoev et al. 1966). Other storage forms of CHOs are soluble sugars, mainly sucrose, glucose, and fructose (Jones et al. 1999, Sepúlveda and Kliewer 1986). These non-structural CHO reserves support production of new roots, shoots, leaves, and clusters early in the new season (Greven et al. 2005). The storage of non-structural CHO is generally greatest in the root tissue of grapevines (Bates et al. 2002, Uys and Orffer 1983), and root-derived CHO was found to be the principal reserve source for the annual resumption of growth in grapevines (Bates et al. 2002, Loescher et al. 1990, Zapata et al. 2004). Reserve CHOs accumulate to their greatest concentrations in all plant organs by leaf fall in autumn (Bennett et al. 2005, Williams 1996, Winkler and Williams 1945) and are mostly retained during ectodormancy (abbreviated to 'dormancy' throughout this work), apart from small respiratory losses. During leaf senescence in autumn, hydrolytic enzymes break down leaf proteins, $\mathrm{CHO}$, and nucleic acids that are transported in the phloem back into the permanent plant structure, where they are stored during dormancy and remobilized in spring for early growth. Many minerals are also transported out of senescing leaves back into the vine's permanent structure. Of reserve starch in the vine present at budburst, $78 \%$ is used for shoot and root growth by the time of bloom (Bates et al. 2002). 
In autumn, frosts can cause virtually instantaneous leaf death, premature leaf abscission, loss of postharvest photosynthate production, and loss of an important pool of organic and inorganic nutrients. With almost 2000 wind machines available in Marlborough vineyards to combat potential spring frosts, the question is raised whether it would be desirable or cost-effective to use these machines to prevent autumn frost damage. Management practices after harvest such as pre-leaf fall pruning may also alter the capacity of the vine to "recycle" nutrients and replenish storage reserves.

The period immediately following harvest is important for root growth and nutrient uptake in grapevines (Conradie 1986, Mullins et al. 1992). Sufficient late-season nitrogen (N) uptake and reserve accumulation is essential, since early $\mathrm{N}$ demand in spring cannot be met by root uptake (Conradie 1986, Löhnertz et al. 1989, Peacock et al. 1989). Imbalance in source-sink relationships in late season may limit potential assimilate supply to the roots in autumn. Autumn-stored assimilates are preferentially used for early shoot growth the following spring (Yang and Hori 1979).

Mobilization of $\mathrm{CHO}$ reserves in spring supplies energy and carbon skeletons for new shoot growth and flower development until photosynthesis becomes the primary source of carbon. Therefore, the postharvest period may be important in determining vine vigor and productivity in the following season. It also allows remobilization of $\mathrm{N}$ from senescing leaves to the trunk and roots.

The capacity for reserve replenishment increases after midberry ripening (Candolfi-Vasconcelos et al. 1994a). Loss of photosynthetically active leaf area or excessive crop loads may deplete storage reserves (Candolfi-Vasconcelos et al. 1994b). High crop loads may reduce the amount of accumulated vine reserves before harvest and the delayed fruit maturation may shorten the postharvest period (Greven et al. 2015). These effects reduce the vine's capacity to accumulate $\mathrm{CHO}$ for the following season. Some studies, however, found no effect of crop load (Bravdo et al. 1985) or harvest date (Wample and Bary 1992) on cane reserve $\mathrm{CHO}$ concentration, despite reasonably high crop loads. The lack of effect on $\mathrm{CHO}$ reserves could not be ascribed to sink limitation, since both studies reported moderate to high crop loads, but it could be explained by the ability of the vine to maintain equilibrium by adjusting physiological processes (Poni et al. 2006, Smith and Holzapfel 2009).

Photosynthesis declines after harvest (Scholefield et al. 1978) along with leaf N concentration (Williams and Smith 1985), but remains important for reserve replenishment (Loescher et al. 1990). Leaf removal at harvest could reduce yield over $50 \%$ in the following year in Sultana grapes (Scholefield et al. 1978). Fruit set depends strongly on the supply of CHO to the inflorescences, which, in turn, is determined by the carbon balance between vine reserve status, current photosynthesis, and demand by competing sinks (Zapata et al. 2004). Postharvest conditions could affect at least three stages of reproductive development: initiation, differentiation, and fruit set (Holzapfel et al. 2006). However, studies on pruning time in Sauvignon blanc showed no influence of pruning only 10 days after harvest on yield or CHO reserves in the following season (Trought et al. 2011).
Most factors that reduce storage $\mathrm{CHO}$ may concomitantly reduce $\mathrm{N}$ reserves in vines (Loescher et al. 1990). $\mathrm{N}$ is the mineral nutrient for which vines have the greatest demand and the nutrient that most often limits growth (Keller 2010). Differences in vegetative growth and yield were mainly determined by reserve $\mathrm{N}$ and not CHO (Cheng et al. 2004). Nitrogen and carbon are incorporated together in many physiologically important plant compounds such as amino acids, proteins, and enzymes (Kozlowski and Pallardy 1997). Leaf area development during spring growth correlated directly with $\mathrm{N}$ mobilization from wood (Weyand and Schultz 2006). Many studies have shown that $\mathrm{CHO}$ reserves are used to develop new grapevine shoots and inflorescences in the following spring, until shoots develop eight leaves and start exporting CHO (Scholefield et al. 1978, Yang and Hori 1979). Investigations into the effect of early pruning, and hence leaf removal from vines, have been undertaken in Australia on Shiraz vines in Wagga Wagga (Field et al. 2009) and in Semillon vines in Riverina (Holzapfel et al. 2006). Both these areas are warm climate grapegrowing regions where leaves stay on the vines for many weeks after harvest, replenishing vine reserves. This longer period from harvest until leaf senescence (Field et al. 2009, Holzapfel et al. 2006) may be the main reason vineyards in warmer regions can support higher crop loads than those in cooler regions. In highly productive vineyards, it is important to sustain yields through good management and to optimize vine vigor and productivity for the subsequent season by manipulating the length and efficacy of the postharvest period; for instance, by frost protection, irrigation, and nutrition management. However, in cool climate regions such as New Zealand, where autumn temperatures are often limiting, it may be argued that postharvest $\mathrm{CHO}$ accumulation is insufficient to warrant the expense of cultural practices aimed at maintaining an active canopy.

The present work investigates the role of the postharvest period on vine carbon and N status of high-yielding Sauvignon blanc vines in Marlborough, New Zealand as vines approached onset of winter dormancy. Besides postharvest leaf removal, an additional treatment was applied: increasing the number of canes laid down at pruning time from the standard four canes for Marlborough Sauvignon blanc, to six canes. It was hypothesized that the additional fruit produced from these nodes would increase the drain on vine reserves and therefore emphasize their importance.

The objectives of this work were: A) to quantify photosynthetic net carbon gain from after harvest until leaf fall; B) to investigate whether it is possible to maintain high crop yields without the contribution of postharvest vine photosynthesis; and C) to evaluate whether postharvest vine management practices such as frost protection are cost-effective in the long term.

\section{Materials and Methods}

This experiment was conducted in a high-vigor Sauvignon blanc vineyard (clone UCD1MS on Schwarzmann rootstock, Vitis riparia $\times V$. rupestris) located at Rowley in Blenheim,

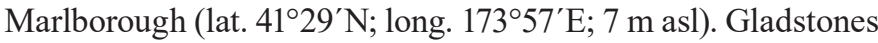
(1992) described Marlborough as a typical cool climate winegrowing region (Figure 1). Marlborough has a heliothermal 
index (Tonietto and Carbonneau 2004) value of 1613, within the 1500 to 1800 class interval suitable for cool climate viticulture.

Vines were planted in 2003 on a deep, well-drained, siltloam soil. The trickle-irrigated vineyard was managed to best industry practice following the New Zealand Sustainable Winegrowing practice (http://www.nzwine.com/swnz/). Vine rows at the trial site were oriented NNW-SSE with $2.8 \times 1.8$ $\mathrm{m}$ row-by-vine spacing. The lowest fruiting wire was $90 \mathrm{~cm}$ from the ground; the top fruiting wire, $110 \mathrm{~cm}$. Vines were cane-pruned to four 12-node canes (Marlborough Sauvignon blanc standard crop load; 48 nodes) or six 12-node canes (very high crop load; 72 nodes). These were designated $48 \mathrm{~N}$ and $72 \mathrm{~N}$, respectively. An additional fruiting wire was placed on the other side of the post, parallel to the top fruiting wire at $110 \mathrm{~cm}$, to accommodate the two additional canes of the $72 \mathrm{~N}$ treatment. All shoots were trained upward as vertical shootpositioned (VSP) vines and positioned between three pairs of movable wires, as is typical in the region. A factorial design of node number $\times$ harvest defoliation was used. All leaves were removed from half the vines immediately after harvest on 16 April 2009, 21 April 2010, and 19 April 2011. The experimental unit was a group of four similar, adjacent vines between two posts, and each treatment was replicated six times.

Gas exchange. Stomatal conductance $\left(\mathrm{g}_{\mathrm{s}}\right)$, photosynthesis (A), transpiration (E), water use efficiency $\left(\mathrm{A} / \mathrm{g}_{\mathrm{s}}\right)$, and sub-stomatal $\mathrm{CO}_{2}$ concentration $\left(\mathrm{C}_{\mathrm{I}}\right)$ were measured on well-exposed primary leaves arising from the tenth node from the shoot base of two representative shoots on each plot at two-week intervals from $\sim 3$ weeks after flowering until leaf fall, using a portable infrared gas analyzer (Ciras-2, PP SYSTEMS). To ensure measurements were fully comparable, gas exchange measurements were performed only under fully saturated light conditions, and therefore the intervals were \pm one day between the fortnightly measurements.

Chlorophyll concentration. Leaf greenness was measured nondestructively with a SPAD-502 chlorophyll meter (Minolta) on the same dates and on the same leaves sampled for gas exchange. Six readings were taken per data leaf and then averaged. Chlorophyll concentration was calculated as described (Candolfi-Vasconcelos et al. 1994b).

Yield components and fruit composition. The fruit were harvested on 15 April 2009, 20 April 2010, and 19 April 2011. At harvest, the cluster number and yield per vine were record-

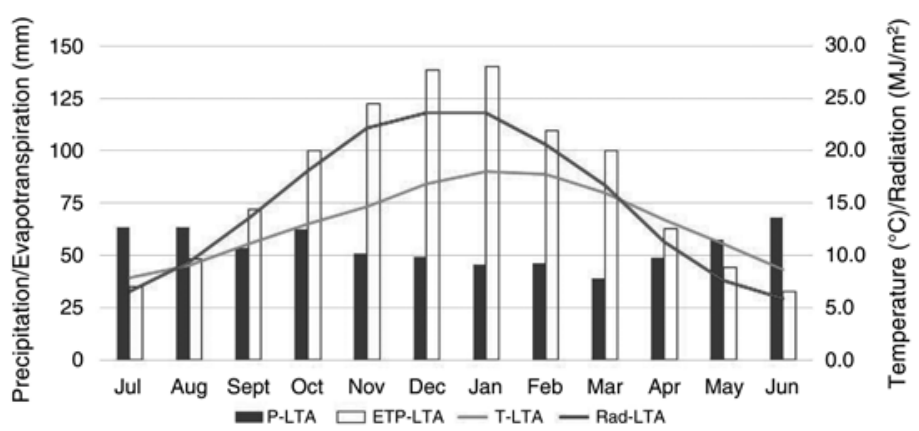

Figure 1 Marlborough long-term average (LTA: 1984 to 2014) climate summary with monthly precipitation (P-LTA), evapotranspiration (ETPLTA), daily average temperature (T-LTA), and radiation ( $M J / m 2)$. ed, from which cluster weight, clusters per shoot, and fruitfulness (fruit weight per shoot) were calculated. A sample of eight clusters per replicate was collected randomly from both sides of the canopy, from lower and upper canes and different positions within the shoot. After stripping all berries from the eight clusters, a subsample of 100 berries per replicate was used to estimate berry weight and berries per cluster. The sample was crushed to determine total soluble solids (TSS), $\mathrm{pH}$, and titratable acidity.

Canopy development and vine vigor. Leaf area was measured at defoliation after harvest on the vines used for the defoliation treatment. All leaves from these vines were removed and weighed. From each bay, the leaf area of a random subsample of 100 leaves was measured using a Li-Cor leaf area meter (LI3100 , Li-Cor, Inc.). The total leaf area per bay was estimated from the total weight of the leaves of the four vines in the bay and the weight:area relationship from the 100-leaf sample. For comparison, point quadrat measurements of 48 points for one vine per plot were taken around veraison. The leaf area was used to calculate the leaf/fruit ratio. Over winter, the dormant canopy was assessed and then all vines were pruned back to their treatment node number. The canopy assessment included a count of all blind nodes (nodes that failed to break bud) and all shoots per vine. Canes were weighed to calculate total vine pruning weight, mean cane weight, clusters per shoot, and the Ravaz index. The Ravaz index represents the ratio of reproductive to vegetative growth, and balanced vines should remain between five and seven (Ravaz 1903). Because of its practicality, this measurement is frequently used in Marlborough Sauvignon blanc. Total vine budburst was calculated by dividing shoots per vine by nodes per vine at the start of the season.

$\mathrm{CHO}$ and $\mathrm{N}$ concentration of the permanent structure. Wood samples from trunk and roots were collected, starting just after dormancy in 2008, at the five-leaf stage. From then on, samples were collected at bloom, lag phase, veraison, mid-ripening, harvest, leaf fall, dormancy, and at the following spring's five-leaf stage through to veraison in 2012. Trunk wood samples were taken from the midsection of the trunk of one vine in each plot to provide an estimate of the $\mathrm{CHO}$ status of grapevine trunks. For this, the old bark was peeled off and using a chisel, a small piece of wood and bark $\sim 2 \mathrm{~cm}$ long, 1 $\mathrm{cm}$ wide, and $3 \mathrm{~mm}$ deep was collected (Candolfi-Vasconcelos and Koblet 1990). Root samples were taken from a mixture of old and younger roots varying from 1 to $5 \mathrm{~mm}$ in diameter at a depth of $\sim 150 \mathrm{~mm}$. The samples ( 0.8 to $1.2 \mathrm{~cm}^{3}$ in volume) were freeze-dried and stored at $-20^{\circ} \mathrm{C}$, then ground to a powder using a ring grinder (Rocklabs Ltd.). The $\mathrm{CHO}$ analysis was undertaken on a 50-mg subsample of ground wood. Carbohydrates were ethanol-extracted, analyzed as described (Smith et al. 1992), and reported as total soluble carbohydrates (TSC) and starch. Total $\mathrm{N}$ was determined using a thermal combustion analyzer (VarioMAX, Elementar Analysensysteme $\mathrm{GmbH})$. Because of large changes in the $\mathrm{CHO}$ found between mid-ripening and harvest, an additional sample was collected preharvest in the 2010 and 2011 seasons.

Data were submitted to analysis of variance using the Genstat 10.2 statistical package (Lawes Agricultural Trust). Mean 
separations were determined by least significant differences at the $5 \%$ level of significance.

\section{Results and Discussion}

Photosynthesis and gas exchange. Overall photosynthetic rates between 12 and $20 \mu \mathrm{mol} \mathrm{CHO} / \mathrm{m}^{2} / \mathrm{s}$ were typical of those reported for normal grape leaf photosynthesis for the times of year. In 2009, leaf photosynthesis was slightly lower early in the season on $72 \mathrm{~N}$ vines, but rates were similar during ripening. This was likely due to the initial 3 to $10 \%$ less chlorophyll in $72 \mathrm{~N}$ vines (Figure 2D). Other key gas exchange parameters (stomatal conductance and transpiration) followed the same patterns for both treatments. No defoliation treatment had been applied at this stage of the study.

In 2010, with the exception of a short period in mid-February when $72 \mathrm{~N}$ vines had a slightly higher photosynthetic rate, there were no gas exchange differences in response to the retained node number (Figure 3 ). The $48 \mathrm{~N}$ vines had 6 to $8 \%$ less chlorophyll throughout the measurement period during 2010; this was counter to what was found during 2009 and 2011 (Figures 2 and 4). The 2009 postharvest defoliation did not affect gas exchange performance in 2010 (Figure 3), nor did eliminating postharvest

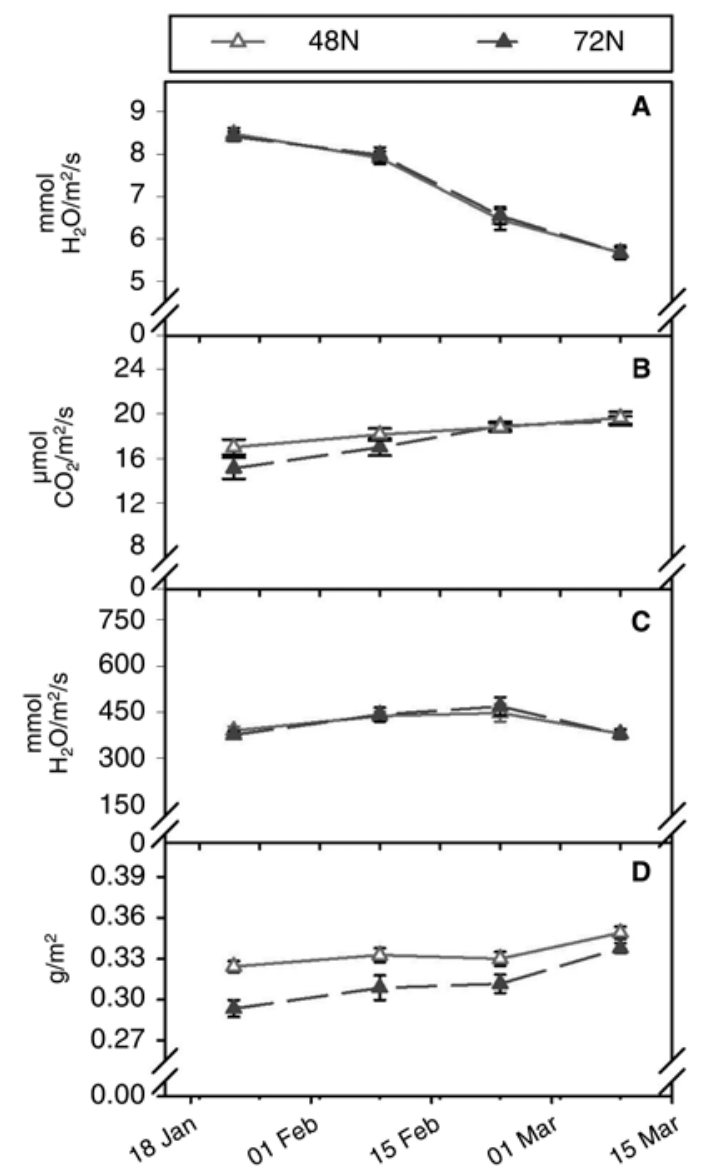

Figure 2 Effect of retaining $48(48 \mathrm{~N})$ or $72(72 \mathrm{~N})$ nodes at pruning time on Sauvignon blanc canopy performance during the 2009 season. (A) transpiration rate, $(\mathbf{B})$ photosynthetic rate, $(\mathbf{C})$ stomatal conductance to water vapor (gs), and (D) leaf chlorophyll concentration. Vertical bars represent \pm SE. Flowering:12 Dec 2008; Veraison: 23 Feb 2009; Harvest: 15 April 2009. photosynthesis by defoliation immediately after harvest affect gas-exchange performance during 2011. However, defoliated vines had slightly less leaf chlorophyll following two consecutive seasons of defoliation (Figure 4).

Many studies have shown that photosynthesis adjusts dynamically to changes in sink demand (Candolfi-Vasconcelos et al. 1994b, Kliewer and Antcliff 1970, Petrie et al. 2000). However, no such adjustment was found in the present study (Figures 2, 3, and 4). Nor were any treatment differences found in canopy density measured by point quadrat in 2010 or 2011 (data not shown). Because neither increased node number (Table 1) nor postharvest defoliation (Table 2) significantly changed leaf area or fruit yield, the absence of significant differences in gasexchange during the 2010 and 2011 seasons did not contradict the literature. In interpreting the gas exchange results, it should be kept in mind that despite the greater number of nodes retained, the $72 \mathrm{~N}$ treatment increased yields only in the first season (Table 1), in agreement with earlier work with Sauvignon blanc in Marlborough (Greven et al. 2014).

Vegetative growth and yield. By increasing the number of nodes from 48 to 72 , highly significant increases in shoot number and, therefore, yield per vine were found in 2009 (Table 1). The number of clusters per shoot was not different, consistent with inflorescence primordium initiation occurring during the previous season, when all vines had the same retained node number. Berries per cluster and berry weight were not affected by increasing the number of nodes, although berry weight showed a trend toward being slightly smaller $(p=0.07)$. Fruit yield on these vines, while significantly greater, increased by $21 \%$ despite the node number set by pruning being $41 \%$ higher for $72 \mathrm{~N}$ vines. This difference between potential and actual yield increase was largely accounted for by the significantly lower budburst on $72 \mathrm{~N}$ vines (and therefore an $84 \%$ higher number of blind buds) and by a $27 \%$ lower mean cane weight (Table 1). No difference was found in leaf area index which, when combined with the $21 \%$ higher yield for $72 \mathrm{~N}$, resulted in a $13 \%$ lower leaf/fruit ratio.

When the $48 \mathrm{~N}$ and $72 \mathrm{~N}$ treatments were again applied in 2010 , the number of shoots per vine remained significantly different. However, with the shoots arising from the $72 \mathrm{~N}$ treatment now originating from higher-yielding vines of the previous season, the number of blind buds was $75 \%$ greater in the $72 \mathrm{~N}$ treatment than in the $48 \mathrm{~N}$ treatment and clusters/shoot, cluster weight, and berry weight were all reduced (Table 1). None of these yield components were different in the previous year, when both treatments were applied for the first time. The lower mean cane weight, due to the higher shoot number in $72 \mathrm{~N}$ vines, also lowered fruitfulness per shoot so that in 2010 , the yields of $48 \mathrm{~N}$ and $72 \mathrm{~N}$ vines were not different. This is in contrast to a $21 \%$ difference in yield the previous year. Similarly, no significant differences in yield were found in 2011. The higher number of shoots on the $72 \mathrm{~N}$ vines resulted in lower berry and cluster weight, decreasing fruitfulness. The lower cluster weight was likely due to three consecutive years of lower reserves. These results mirror the outcome from a long-term study done in Marlborough with vines pruned to 24, $36,48,60$, or 72 nodes, where strong response mechanisms 
that changed yield components were found according to the number of nodes left at pruning (Greven et al. 2014).

Although the differences in fruit composition were not large in any year (Table 1), delayed maturity in cool climate regions can lead to suboptimal TSS in fruit at harvest. It is therefore essential to avoid yields above which a target Brix maturity value (measuring the TSS content) is unlikely to be achieved (Greven et al. 2015). In 2009, as a consequence of the greater productivity of the 72-node vines, there was a small delay in fruit reaching the targeted maturity, evident from the significantly lower TSS at harvest. In 2010, maturation conditions were very favorable. No differences in TSS or Brix were found between pruning treatments, with all fruit reaching 23 Brix (Table 1). No differences were found in juice $\mathrm{pH}$ or TA between treatments in any year. In 2011 fruit ripening was slower, but all fruit reached the target 20.5 Brix threshold at the same time. Because in 2010 and 2011 yields of both treatments were identical, these similarities in fruit maturity attributes between $48 \mathrm{~N}$ and $72 \mathrm{~N}$ vines were not unexpected (Greven et al. 2014). Despite both treatments having lower yields in 2010, 72N, with 50\% more nodes laid down, dropped yield to equal the $48 \mathrm{~N}$ vines. This relative yield reduction for $72 \mathrm{~N}$ vines between the first and second year of pruning conversion (Table 1) suggests a cumulative reduction in $\mathrm{CHOs}$ over time.

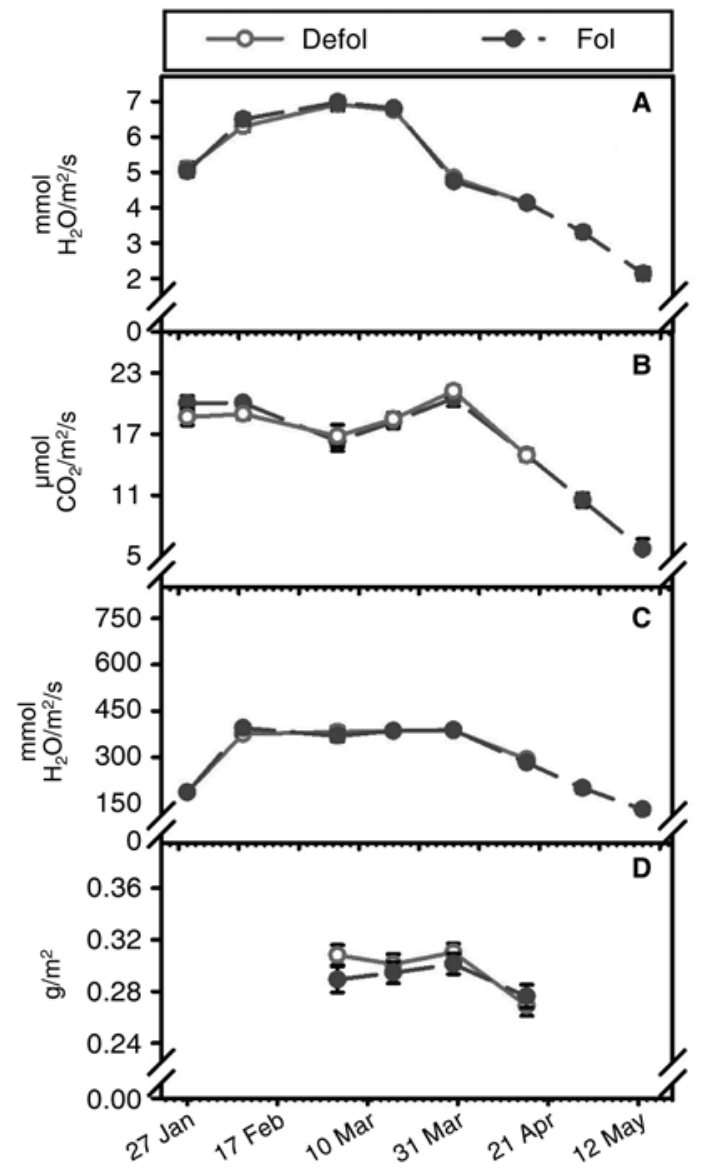

No differences in leaf area per vine or leaf area index (LAI) were found between $48 \mathrm{~N}$ and $72 \mathrm{~N}$ vines in 2009 (Table 1), despite the significantly higher shoot number/vine of $72 \mathrm{~N}$ vines. The additional nodes laid down reduced shoot number per node due to blind budding. However, the $72 \mathrm{~N}$ vines produced a $21 \%$ higher yield. In 2010 also, no differences were found between $48 \mathrm{~N}$ and $72 \mathrm{~N}$ vines in LAI, but this year there was no difference in yield. We suggest the change in leaf/fruit ratio between these two years was because $72 \mathrm{~N}$ vines in 2010 developed from $72-$ node vines in 2009 instead of from 48-node vines in 2008. This forced the $72 \mathrm{~N}$ vine into a new equilibrium between fruit and vegetative growth from the second year on (Greven et al. 2014, Howell 2001).

Winter canopy assessment after harvest in 2009 showed significantly reduced vine pruning weight and cane size and more blind nodes in $72 \mathrm{~N}$ vines (Table 1). This suggests priority partitioning of resources to fruit development early in the season, developing a larger crop on the $72 \mathrm{~N}$ vines at the expense of shoot vegetative development. In 2010 and 2011, despite the greater number of shoots, the total vine pruning weight of $72 \mathrm{~N}$ vines was not different from that of $48 \mathrm{~N}$ vines, due to a much lower individual cane weight. As a consequence, there was no difference in the Ravaz index ( $\mathrm{kg}$ fruit $/ \mathrm{kg}$ pruning wood) between pruning treatments. Despite some significant differences between treatments, in all three years of the trial all vine Ravaz

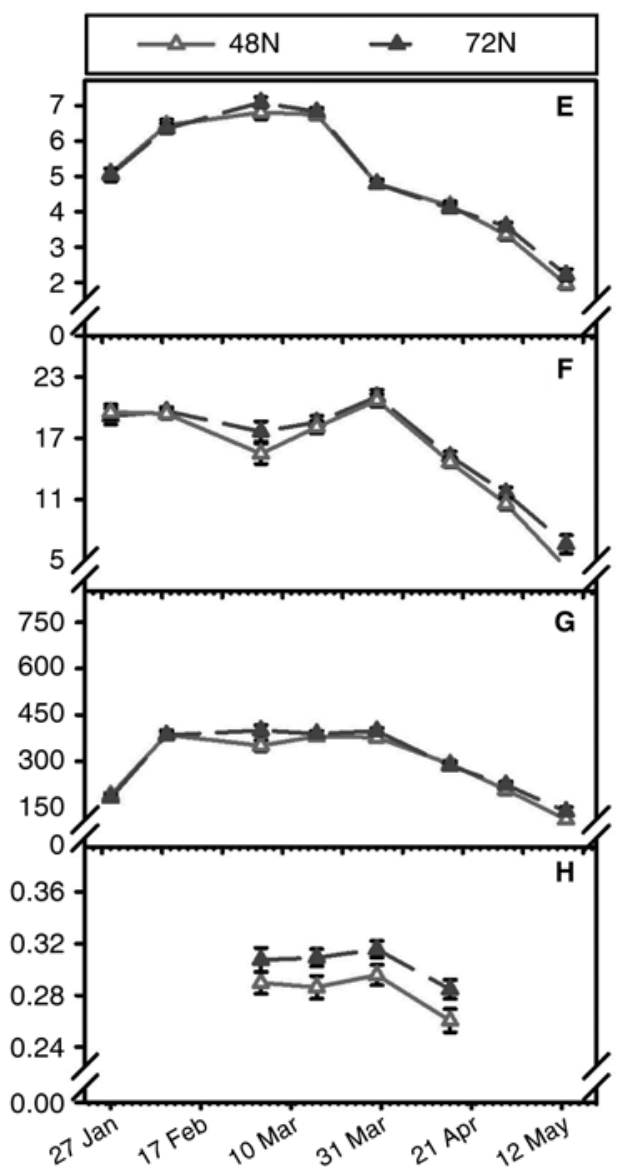

Figure 3 Effects of 2009 postharvest foliated (Fol) or defoliated (Defol) vines, and retaining 48 (48N) or 72 (72N) nodes at pruning time, on Sauvignon blanc canopy performance during 2010. (A, E) transpiration rate, (B, F) photosynthetic rate, (C, G) stomatal conductance (gs), and (D, H) leaf chlorophyll concentration. Vertical bars represent \pm SE. Flowering: 18 Dec 2009; Veraison: 22 Feb 2010; Harvest: 20 April 2010. 
index values stayed between three and six, which is common for Marlborough (Martin, personal communication, 2011).

Defoliation at harvest in 2009 did not affect the 2010 yield or yield components and did not affect fruit composition (Table 2). However, when this treatment was applied two years in a row, defoliated vines in 2011 had significantly lower yields as a result of fewer berries/cluster and hence lower cluster weights. Similar cumulative effects were reported for Semillon in the Riverina region in Australia, where defoliation reduced yield in the subsequent year by $21 \%$, but the yield reduction reached $50 \%$ after two years of postharvest defoliation (Holzapfel et al. 2006). The present study, however, contradicts findings of no differences in yield after pruning vines only 10 days postharvest (Trought et al. 2011). Under cool-climate Marlborough conditions, vines tend to senesce soon after harvest (Bennett et al. 2005, Petrie et al. 2000, Trought et al. 2011).

Across all treatments, postharvest defoliation in 2009 significantly lowered shoot numbers per vine, increased blind buds, and lowered pruning weight and cane weight in 2010 (Table 2). This does signal that postharvest defoliation may reduce vine vegetative development in the following season. However, no differences in leaf layer number were found in any season after postharvest defoliation (data not shown).

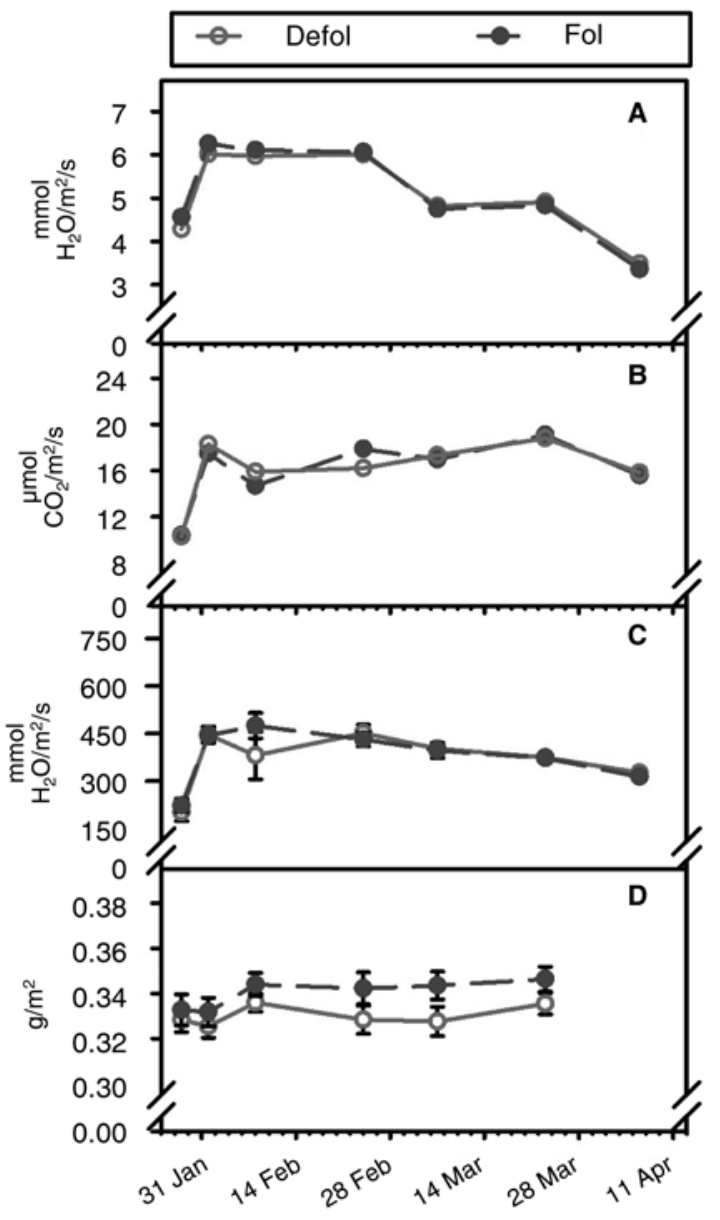

When applied early in the season, at or shortly after full bloom, defoliation over several years had a cumulative effect on yield (Candolfi-Vasconcelos and Koblet 1990). A cumulative effect of postharvest defoliation on yield was demonstrated by Holzapfel et al. (2006) in Riverina, Australia, where very high temperatures mature fruit quickly, enabling the leaves thereafter to recharge the vine CHO reserves. In Marlborough, a cool climate region, this period is very short (Petrie et al. 2000). However, this work shows that even under cool-climate conditions, the lack of $\mathrm{CHO}$ and $\mathrm{N}$ accumulation can significantly affect yield when occurring in consecutive years.

Surprisingly, the defoliation and the pruning treatment effects only compounded for a few parameters. A slight interaction $(p=0.04)$ was found in 2010, when the number of shoots per vine was only lower in defoliated $72 \mathrm{~N}$ vines. Total vine $\%$ budburst decreased for all $72 \mathrm{~N}$ treatments below that of $48 \mathrm{~N}$ vines, but more so for defoliated $72 \mathrm{~N}$ vines. This trend was not significant in 2010, but became significant in 2011. The opposite was true for blind nodes per vine (Table 3). Yield components showed some interactions, especially after three years of treatments. In 2011, defoliation reduced clusters/vine more for $48 \mathrm{~N}$ than for $72 \mathrm{~N}$ and berry weight was smallest for

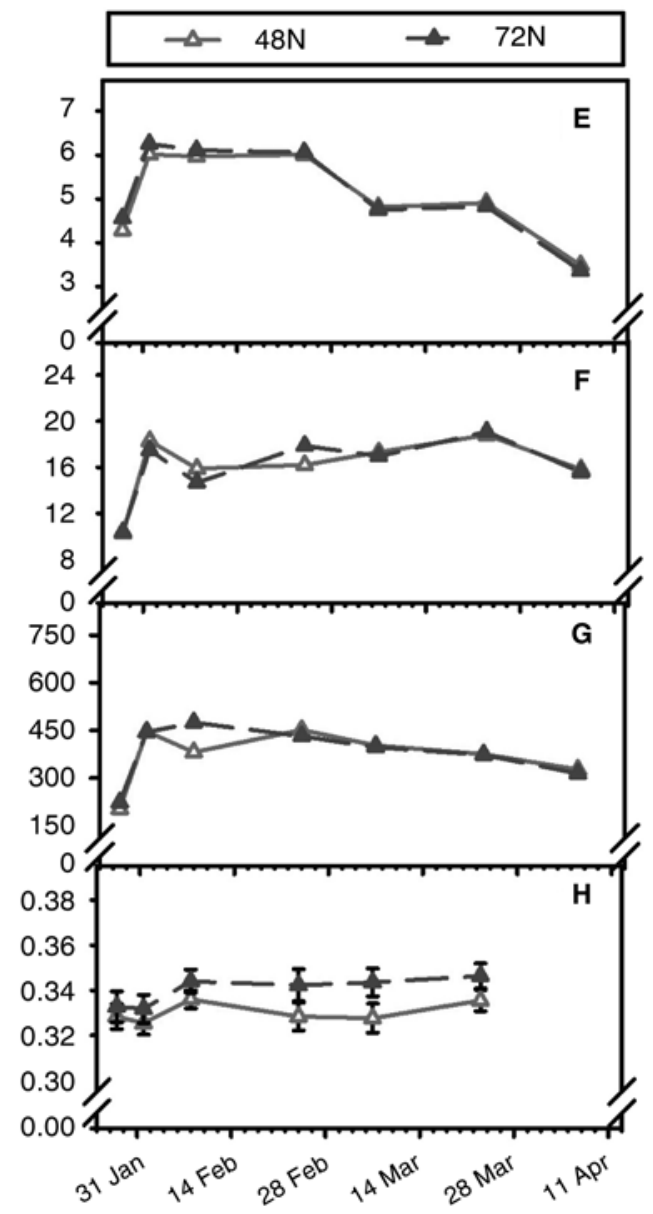

Figure 4 Effects of 2010 postharvest foliated (Fol) or defoliated (Defol) vines, and retaining 48 (48N) or 72 (72N) nodes at pruning time, on Sauvignon blanc canopy performance during 2011. (A, E) transpiration rate, (B, F) photosynthetic rate, (C, G) stomatal conductance (gs), and (D, H) leaf chlorophyll concentration. Vertical bars represent \pm SE. Flowering: 13 Dec 2010; Veraison:15 Feb 2011; Harvest:19 April 2011. 
defoliated $72 \mathrm{~N}$ vines. A similar, but not significant, trend was found for cluster weight in 2010 and 2011 and clusters/vine and berry weight in 2010. Despite the treatment interactions observed in specific yield components, there was no interaction between defoliation and laid down nodes for yield/vine.
Pruning weight and cane mass reduced over time and lower cane mass may affect productivity in the following season.

Total N. Total $\mathrm{N}$ in the roots and trunk followed the same seasonal patterns in all three seasons, varying from 0.8 to 1.7 $\mathrm{mg} / \mathrm{g}$ dry matter (DM) for roots and 0.3 and $0.8 \mathrm{mg} / \mathrm{g} \mathrm{DM}$ for

Table 1 Fruit yield components, fruit composition, and vine growth characteristics of Sauvignon blanc pruned to $48(48 \mathrm{~N})$ or 72 nodes $(72 \mathrm{~N})$ per vine.

\begin{tabular}{|c|c|c|c|c|c|c|c|c|c|}
\hline \multirow[b]{2}{*}{ Treatment } & \multicolumn{3}{|c|}{2009} & \multicolumn{3}{|c|}{2010} & \multicolumn{3}{|c|}{2011} \\
\hline & $48 N$ & $72 \mathrm{~N}$ & Sig. ${ }^{a}$ & $48 N$ & $72 \mathrm{~N}$ & Sig. & $48 N$ & $72 \mathrm{~N}$ & Sig. \\
\hline \multicolumn{10}{|l|}{ Fruit } \\
\hline Yield (kg/vine) & 12.7 & 15.4 & $* * *$ & 9.3 & 9.8 & ns & 10.5 & 11.2 & ns \\
\hline Clusters/shoot & 1.85 & 1.83 & ns & 1.60 & 1.43 & * & 1.48 & 1.51 & ns \\
\hline Cluster weight (g) & 129 & 124 & ns & 118 & 109 & * & 146 & 123 & $* * *$ \\
\hline Fruitfulness (g/shoot) & 238 & 223 & * & 209 & 185 & $\star \star$ & 263 & 229 & * \\
\hline Berries/cluster & 84 & 86 & ns & 76 & 80 & ns & 88 & 85 & ns \\
\hline Berry weight (g) & 2.06 & 1.99 & ns & 1.98 & 1.89 & * & 1.88 & 1.83 & ns \\
\hline Total soluble solids (Brix) & 20.5 & 19.9 & * & 23.5 & 23 & ns & 20.3 & 20.5 & ns \\
\hline Juice $\mathrm{pH}$ & 2.88 & 2.86 & ns & 2.95 & 2.93 & ns & 3.01 & 2.99 & ns \\
\hline $\mathrm{TA}(\mathrm{g} / \mathrm{L})$ & 12.81 & 12.55 & ns & 11.83 & 12.26 & ns & 11.48 & 11.13 & ns \\
\hline \multicolumn{10}{|l|}{ Vine } \\
\hline Budburst $(\%)^{\mathrm{b}}$ & 99 & 88 & $\star * *$ & 89 & 93 & ns & 96 & 77 & *** \\
\hline No. shoots/vine & 52.0 & 66.0 & *** & 44.2 & 53.0 & *** & 47.5 & 55.2 & *** \\
\hline Blind buds & 9.5 & 17.2 & *** & 9.8 & 17.2 & *** & 10 & 22.6 & *** \\
\hline $\operatorname{LAI}\left(\mathrm{m}^{2} / \mathrm{m}^{2}\right)^{\mathrm{c}}$ & 3.1 & 3.3 & ns & 2.6 & 2.7 & ns & 3 & 3.3 & ns \\
\hline Leaf/fruit ratio $\left(\mathrm{cm}^{2} / \mathrm{g}\right)$ & 12.3 & 10.7 & * & 13.1 & 13.7 & ns & 15.0 & 14.7 & ns \\
\hline Pruning weight (kg/vine $)^{\mathrm{d}}$ & 2.4 & 2.2 & * & 2 & 2 & ns & 2.2 & 2.09 & ns \\
\hline Mean cane weight $(\mathrm{g})$ & 49 & 36 & *** & 44 & 37 & ** & 46.3 & 38 & *** \\
\hline Ravaz index & 5.5 & 7.2 & *** & 4.8 & 5.0 & ns & 4.7 & 5.4 & ** \\
\hline
\end{tabular}

a* ${ }^{* *}$, and ${ }^{* * *}$ indicate significance at $p<0.05,0.01$, and 0.001 , respectively. ns: not significant.

bVine \% budburst: shoots per vine/retained count nodes per vine

'Leaf area index (LAI) and Leaf/fruit ratio were calculated only for defoliated vines

dTotal pruning weight: cane + two-year-old wood weight.

Table 2 Fruit yield, yield components, and vine growth characteristics of Sauvignon blanc vines that were defoliated (Defol) or not defoliated (Fol) after harvest in 2009, 2010, and 2011.

\begin{tabular}{|c|c|c|c|c|c|c|c|c|c|}
\hline \multirow[b]{2}{*}{ Treatment } & \multicolumn{3}{|c|}{2009} & \multicolumn{3}{|c|}{2010} & \multicolumn{3}{|c|}{2011} \\
\hline & Defol & Fol & Sig. ${ }^{a}$ & Defol & Fol & Sig. & Defol & Fol & Sig. \\
\hline \multicolumn{10}{|l|}{ Fruit } \\
\hline Yield (kg/vine) & & 14.0 & & 9.2 & 9.9 & ns & 10.0 & 11.6 & ** \\
\hline Clusters/shoot & & 1.83 & & 1.54 & 1.48 & ns & 1.60 & 1.57 & ns \\
\hline Cluster weight (g) & & 126 & & 113 & 113 & ns & 127 & 143 & * \\
\hline Fruitfulness (g/shoot) & & 226 & & 197 & 195 & ns & 233 & 260 & ** \\
\hline Berries/cluster & & $\mathrm{n} / \mathrm{a}$ & & 78 & 78 & ns & 82 & 91 & * \\
\hline Berry weight (g) & & 2.02 & & 1.92 & 1.94 & ns & 1.86 & 1.86 & ns \\
\hline Total soluble solids (Brix) & & 20.3 & & 23.3 & 23.1 & ns & 20.9 & 19.9 & ns \\
\hline Juice pH & & 2.88 & & 2.94 & 2.95 & ns & 3.01 & 2.99 & ns \\
\hline Titratable acidity $(\mathrm{g} / \mathrm{L})$ & & 12.46 & & 12.06 & 12.06 & ns & 10.87 & 11.73 & ns \\
\hline \multicolumn{10}{|l|}{ Vine } \\
\hline Budburst $(\%)^{\mathrm{b}}$ & 94 & 94 & ns & 92 & 91 & ns & 83 & 90 & $* * *$ \\
\hline No. shoots/vine & 58.7 & 59.3 & ns & 47.1 & 50.8 & 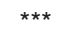 & 50.5 & 52.3 & ns \\
\hline Blind buds & 13.9 & 13.4 & ns & 16.3 & 11.4 & *** & 19 & 14 & *** \\
\hline $\mathrm{LAI}\left(\mathrm{m}^{2} / \mathrm{m}^{2}\right)^{\mathrm{c}}$ & 3.2 & & & 2.7 & & & 3.2 & & \\
\hline Leaf/fruit ratio $\left(\mathrm{cm}^{2} / \mathrm{g}\right)$ & 11.5 & & & 13.4 & & & 14.9 & & \\
\hline Pruning weight (kg/vine $)^{d}$ & 2.3 & 2.2 & ns & 1.8 & 2.2 & *** & 1.99 & 2.3 & *** \\
\hline Cane weight $(\mathrm{g})$ & 43.0 & 42.5 & ns & 37.0 & 40.8 & * & 39.7 & 44.6 & * \\
\hline Ravaz Index & 6.3 & 6.4 & ns & 5.2 & 4.6 & * & 5.0 & 5.1 & ns \\
\hline
\end{tabular}

${ }^{* *}{ }^{* *}$, and ${ }^{* * *}$ indicate significance at $p<0.05,0.01$, and 0.001 , respectively. ns: not significant.

bVine \% budburst: shoots per vine/retained count nodes per vine

'Leaf area index (LAI) and Leaf/fruit ratio were calculated only for defoliated vines

dTotal pruning weight: cane + two-year-old wood weight. 
trunk. N concentrations in both roots and trunk were greatest just after budburst in early spring (five-leaf stage), after which they declined to a minimum at veraison. During the rest of the growing season $\mathrm{N}$ remained fairly low, but it increased sharply after harvest, was restored to close to the annual maxima around leaf fall, and remained at high concentrations until early spring the following year (Figures 5 and 6 ).

No difference was found between defoliated and foliated vines during any of the periods of low $\mathrm{N}$ between bloom and harvest (Figure 5). Dormant-period N reserves were not monitored prior to the start of the experiment in the spring of the 2008 to 2009 season. During dormancy before the start of the 2010 season, slightly lower $\mathrm{N}$ was measured in defoliated vines. However, during the third and last season (2011), vine trunks subjected to, at that point, three years of postharvest defoliation had $50 \%$ less $\mathrm{N}$ than foliated vines due to their continued inability to build up $\mathrm{N}$ reserves. This overall trend for lower vine $\mathrm{N}$ is likely to have contributed to the reduced fruitfulness of defoliated vines seen in 2011. Root $\mathrm{N}$ was less affected by defoliation than trunk $\mathrm{N}$.

Changes in trunk total $\mathrm{N}$ were initially unaffected by the pruning treatment, but in the second season, there was a slight tendency toward a lower seasonal minimum $\mathrm{N}$ in $72 \mathrm{~N}$ vines (Figure 6). Differences in root $\mathrm{N}$ associated with pruning were more marked, with $72 \mathrm{~N}$ vines showing progressively slower recovery of $\mathrm{N}$ postveraison and during dormancy than $48 \mathrm{~N}$ vines.

The trends found in this study only partially correspond with South African studies with Chenin blanc in which N uptake

Table 3 Interactions of postharvest defoliation ( $\mathrm{Fol}=$ foliated,

Defol $=$ defoliated $)$ and pruning treatments $(48$ nodes $=48 \mathrm{~N}$ and 72 nodes $=72 \mathrm{~N}$ ) for fruit yield, yield components, and vine growth characteristics of Sauvignon blanc in 2010 and 2011.

\begin{tabular}{|c|c|c|c|c|c|}
\hline & \multicolumn{2}{|c|}{$48 \mathrm{~N}$} & \multicolumn{2}{|c|}{$72 \mathrm{~N}$} & \multirow[b]{2}{*}{ Sig. ${ }^{a}$} \\
\hline & Fol & Defol & Fol & Defol & \\
\hline \multicolumn{6}{|c|}{$\%$ Budburst } \\
\hline 2010 & 99.8 & 93.9 & 89.6 & 79.8 & ns \\
\hline 2011 & $97.1 \mathrm{a}$ & $94.1 \mathrm{a}$ & $82.2 \mathrm{~b}$ & $72.1 \mathrm{c}$ & * \\
\hline \multicolumn{6}{|c|}{ Blind nodes/vine } \\
\hline 2010 & 7.7 & 11.5 & 14.5 & 20.3 & ns \\
\hline 2011 & $8.8 \mathrm{c}$ & $11.3 \mathrm{c}$ & $18.9 \mathrm{~b}$ & $26.3 \mathrm{a}$ & * \\
\hline \multicolumn{6}{|c|}{ Total shoots } \\
\hline 2010 & $50.8 \mathrm{~b}$ & $47.8 \mathrm{~b}$ & $67.1 \mathrm{a}$ & $59.0 \mathrm{ab}$ & * \\
\hline 2011 & 47.6 & 47.4 & 56.9 & 53.5 & ns \\
\hline \multicolumn{6}{|c|}{ Yield/vine (kg) } \\
\hline 2010 & 9.3 & 9.3 & 10.3 & 9.2 & ns \\
\hline 2011 & 11.5 & 9.4 & 11.8 & 10.6 & ns \\
\hline \multicolumn{6}{|c|}{ Clusters/vine } \\
\hline 2010 & 80.2 & 77.8 & 62.9 & 57.1 & ns \\
\hline 2011 & $76.4 \mathrm{~b}$ & $66.8 \mathrm{c}$ & $87.3 \mathrm{a}$ & $95.4 \mathrm{a}$ & * \\
\hline \multicolumn{6}{|c|}{ Cluster weight (g) } \\
\hline 2010 & 117.2 & 119.2 & 110.3 & 106.9 & ns \\
\hline 2011 & 150.2 & 142.5 & 135.6 & 110.7 & ns \\
\hline \multicolumn{6}{|c|}{ Berry weight (g) } \\
\hline 2010 & 2 & 2 & 1.9 & 1.9 & ns \\
\hline 2011 & $1.9 a b$ & $1.9 \mathrm{a}$ & $1.9 a b$ & $1.8 \mathrm{~b}$ & * \\
\hline
\end{tabular}

$a^{*}$ indicates significance at $p<0.05$. ns: not significant. Means followed by the same letter within a row are not significantly different. was reported from bloom to veraison and after harvest (Conradie 1986). Figures 5 and 6 indicate a clear increase in $\mathrm{N}$ after harvest, but the pattern between bloom and veraison was a decline rather than an increase. This difference is likely because our study measured only $\mathrm{N}$ in roots and trunk and not $\mathrm{N}$ that was incorporated into the fresh vegetative parts and developing fruit. This study and others (Conradie 1986, Mullins et al. 1992) clearly illustrate a reduction in permanent structure $\mathrm{N}$ until harvest, suggesting a strong demand for $\mathrm{N}$ by the developing canopy and fruit. Reduced $\mathrm{N}$ in the trunks of defoliated vines

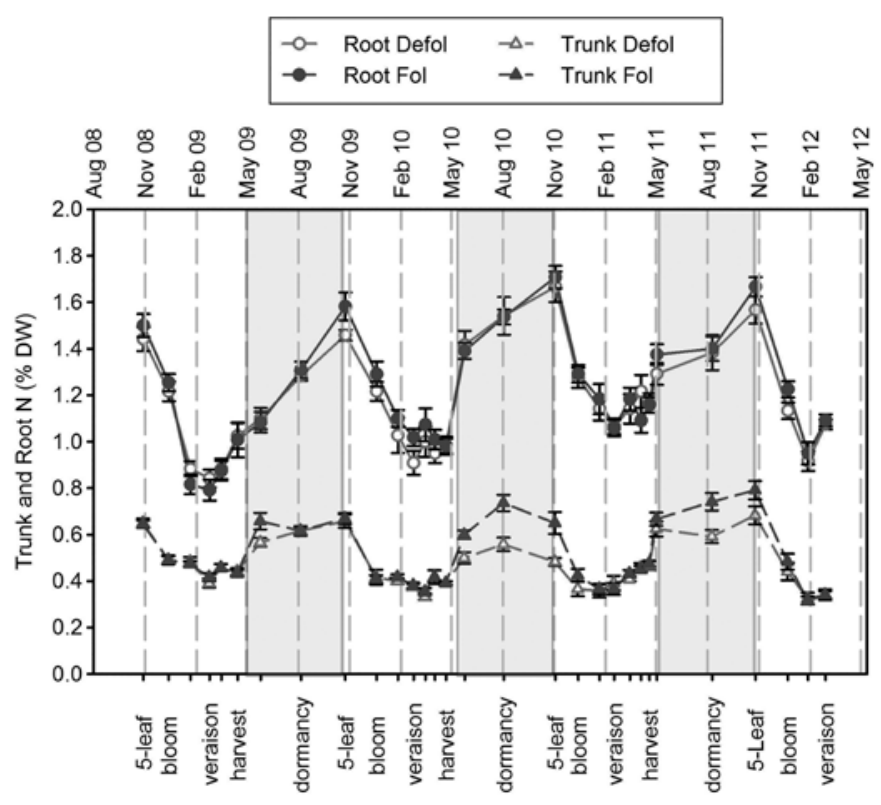

Figure 5 Total nitrogen $(\mathrm{N})$ concentration in trunk and root tissue from Sauvignon blanc grapevines that were defoliated (Defol) or not (Fol) immediately after harvest (15 April 2009, 21 April 2010, and 19 April 2011). Error bars indicate $\pm \mathrm{SE}$.

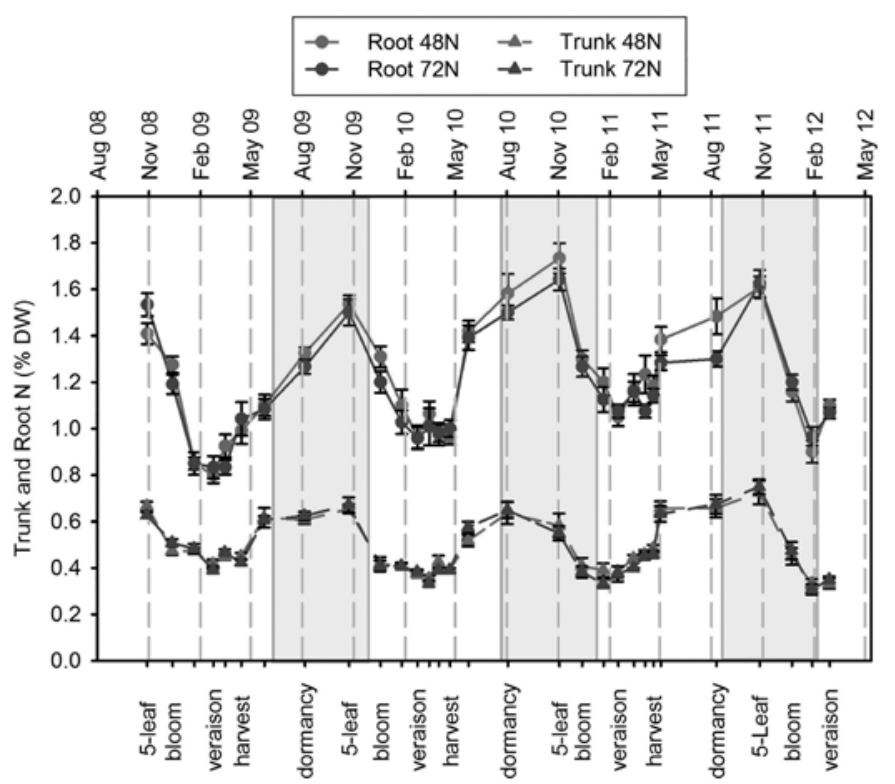

Figure 6 Total nitrogen $(\mathrm{N})$ concentration measured in trunk and root tissue from Sauvignon blanc grapevines with $48(48 \mathrm{~N})$ or 72 nodes $(72 \mathrm{~N})$ retained at pruning, with error bars indicating $\pm \mathrm{SE}$. 
(Figure 6) may affect canopy development in the following season and cumulatively may reduce vine development, productivity, and fruit quality. Lower cane mass as such may affect productivity in the following season (Eltom et al. 2014).

Over the three years of the trial, despite a sharp drop in $\mathrm{N}$ after the start of the growing season, the non-defoliated vines could replenish $\mathrm{N}$ to at least predormancy concentrations every year. However, postharvest defoliation did reduce trunk N (Figure 6). Other research has also found that late-season defoliation resulted in $\mathrm{N}$ deficiency in the following season (Loescher et al. 1990). Complete defoliation prohibits nutrient resorption from the leaves and reallocation to storage, but also greatly reduces late-season nutrient uptake from the soil because it eliminates transpiration. Lower spur nutrient concentrations following harvest defoliation of Semillon vines were reported and it was proposed that both vegetative growth and yield in the following years were more affected by the lower $\mathrm{N}$ status than by $\mathrm{CHO}$ status (Holzapfel et al. 2006). Labeled N stored in roots during dormancy was remobilized early to support spring growth, with contribution from new-season $\mathrm{N}$ uptake being insignificant in new leaf tissue until bloom (Peacock et al. 1989). Our data show a strong decline in $\mathrm{N}$ in both trunk and roots from early in the growing season until well past bloom. This decline was followed by an equally strong accumulation of $\mathrm{N}$ from postveraison throughout the winter, until spring (Figures 5 and 6).

$\mathrm{N}$ in vine roots increased continuously from harvest, through the dormant period, until early in the next season. This suggests that vine root systems remain active in $\mathrm{N}$ uptake throughout winter in the Marlborough climate. Reduced $\mathrm{N}$ in roots occurred with high node and defoliation treatments. Both treatments could reasonably lead to reduced root development and activity in parallel with altered canopy responses, which could lead to small but progressive cumulative decline in root $\mathrm{N}$.

CHO. The total nonstructural $\mathrm{CHO}$ present in trunk and roots are available in soluble (sugars) and insoluble forms (starch). Starch is the stable form in storage tissues during dormancy and requires hydrolysis in spring before transport through the xylem as TSC. From the outset, dynamic yearly changes in $\mathrm{CHO}$ were evident in both root and trunk tissues. The total nonstructural $\mathrm{CHO}$ mainly consisted of starch at most sampling times, with TSC making up only $20 \%$ of $\mathrm{CHO}$ in the roots and 10 to $60 \%$ in the trunks (Figure 7). When comparing root and trunk $\mathrm{CHO}$, it is clear that the TSC dynamics were very similar, but with almost three times the concentration in the trunk during dormancy ( 85 to $90 \mathrm{mg} / \mathrm{g}$ dry weight [DW]) than in the root (25 to $35 \mathrm{mg} / \mathrm{g} \mathrm{DW}$ ), with both tissues reaching very similar minimum concentrations during the growing season (10 to $20 \mathrm{mg} / \mathrm{g} \mathrm{DW}$ ). This was not true for starch: despite the changes in concentration being similar and parallel, after harvest, trunk starch was reduced faster than root starch and increased less rapidly after dormancy. Root starch and trunk starch followed a similar and parallel trend, with higher concentrations (120 to $160 \mathrm{mg} / \mathrm{g} \mathrm{DW}$ ) toward harvest and lower concentrations (40 to $100 \mathrm{mg} / \mathrm{g} \mathrm{DW}$ ) during dormancy and early spring growth, but both curves demonstrate considerable dynamic variability in $\mathrm{CHO}$ at any period (Figures 7 and 8).
TSC. TSC in both trunk and roots declined postbloom during the first year, from lag phase to mid-ripening. During the two following years, TSC slowly increased from bloom to mid-ripening, thereafter recovering rapidly to reach maximum concentration during vine dormancy. From harvest on, TSC in the roots was maintained at a constant, but lower concentration than in the trunk (Figures 7 and 8).

In the trunk, the TSC concentration increased strongly into the dormant period. Low $\mathrm{CHO}$ reserves can reduce winter hardiness (Wample and Bary 1992). The accumulation of sugars in the trunk as dormancy approaches might therefore be attributed to the vine acclimating to low temperatures (Hamman et al. 1996). These sugars were likely converted from starch as trunk starch decreased toward dormancy or could have resulted from new assimilate from the leaf canopy during reserve replenishment (Figures 7 and 8). Early leaf drop or defoliation immediately after harvest therefore reduces the leaf supply of $\mathrm{CHO}$ needed to harden-off the shoots before winter. We suggest that this was compensated for by the stronger remobilization of reserve $\mathrm{CHO}$ in the defoliated vines (Figures 7 and 8). Unfortunately, most of these carbohydrates are lost when most canes are pruned from the vines at winter pruning. The high TSC concentrations may be evidence of the trunk as a transition buffer pool between vine canes and root $\mathrm{CHO}$ storage at the onset of dormancy.

Starch. Trunk starch was lowest (20 mg/g DW) during the lag phase after bloom, but increased rapidly until harvest to reach $170 \mathrm{mg} / \mathrm{g} \mathrm{DW}$, a seven-fold increase from the minimum (Figures 7 and 8). Both root and trunk starch increased rapidly, especially postveraison, to achieve relatively high concentrations by harvest. After harvest, starch in both trunk and root declined. The decline in starch, which was more obvious in roots, may be associated with the demand for $\mathrm{CHO}$ to increase winter hardiness or to develop new roots in autumn (Conradie and Bonnardot 2005, Coombe 1995, Williams 1996). Overall, starch accumulation patterns showed very dynamic changes over quite short durations within the seasonal growth cycle, demonstrating a highly responsive carbon economy. It is therefore probable that reserves can increase rapidly when growth demand from vine, fruit, and root sinks alters during seasonal development. The shifts in major competing sink activity at these times are the decline in the vegetative sink as shoot growth declines, as the fruit demand in that period remains high during ripening and maturation until veraison (Coombe 1995). The $\mathrm{CHO}$ change on individual sample dates was much more consistent over the years in trunks than in roots. This could be due to the greater difficulty in attaining consistent root sampling than trunk sampling. However, over time, clear patterns were seen between trunk and root, suggesting that the vine may sequester $\mathrm{CHO}$ reserves in the most accessible storage sink (the trunk) during the main growing season, with accumulation into the roots occurring when the demands from major competitive sinks decline. For example, in the last phase of fruit development, postveraison ripening immediately before harvest, the crop sink has a relatively low demand for $\mathrm{CHO}$ because significant starch accumulation occurs in both trunk and roots at this time. Another study agrees that roots, rather than 
fruit, are the priority sink for $\mathrm{CHO}$ during the last stages of ripening (Candolfi-Vasconcelos et al. 1994a).

Root $\mathrm{N}$ and root sugar followed the same trend, but while root sugar reached its maximum at dormancy and then declined rapidly, root $\mathrm{N}$ reached its maximum at the five-leaf stage or two months later (Figures 5, 6, 7, and 8). Trunk sugars and trunk $\mathrm{N}$ were closely related and both reached their maximum concentration ( 85 and $0.8 \mathrm{mg} / \mathrm{g} \mathrm{DW}$, respectively) around dormancy $\left(\mathrm{R}^{2}=0.63\right)$.

The annual dynamics of these two CHO pools differed very little between treatments. Carbon sink concentration dynamics were highly responsive to changes in crop load, were also implicated in changes in canopy development, and may offer a partial explanation for the root starch patterns observed. We suggest that grapevine $\mathrm{N}$ and $\mathrm{CHO}$ partitioning favors the survival of the permanent structure over increasing vine size and yield. After harvest in all three years, starch declined in both root and trunk, although somewhat more slowly in the roots during the second year.

After harvest, $\mathrm{CHO}$ are mobilized into sugars and moved from the trunk to the roots, which are the most important sites of accumulation of $\mathrm{CHO}$ for vine reserves (Bates et al. 2002, Scholefield et al. 1978, Uys and Orffer 1983, Winkler and Williams 1945). These trends in CHO reserve pool dynamics, considered together, suggest that the trunk may function as a significant but transitional reserve pool between the root reserve
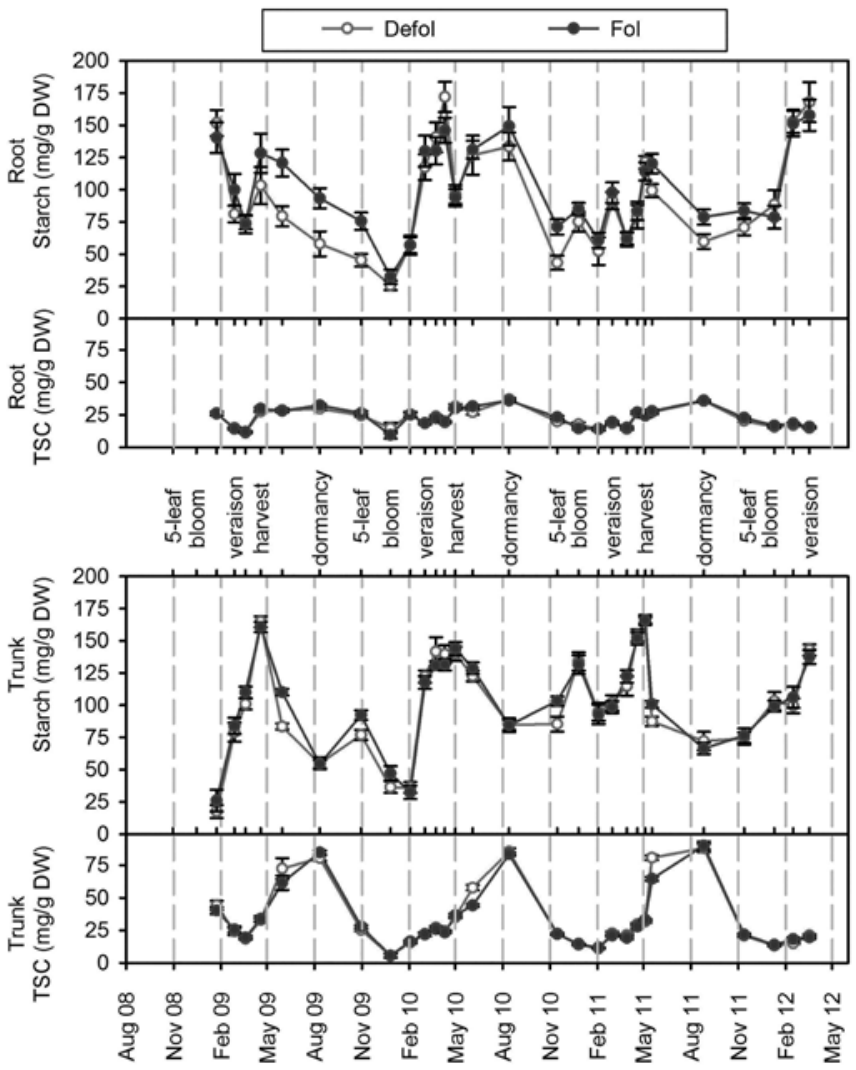

Figure 7 Total soluble carbohydrates (TSC) and starch in root and trunk tissue from Sauvignon blanc grapevines that were defoliated (Defol) or not (Fol) immediately after harvest (15 April 2009, 21 April 2010, and 19 April 2011), with error bars indicating \pm SE. and the rest of the vine. This is supported by the similarity in trunk $\mathrm{CHO}$ dynamics across both pruning systems and defoliation treatments.

Starch concentrations were generally lower in the roots of defoliated vines (Figure 7). The effect was increased (nonsignificantly) by the additional stress factor of more nodes retained. In all three years, starch dropped rapidly in roots after harvest, but even more so in trunks. These findings are similar to responses found in Shiraz vines in Wagga Wagga (Field et al. 2009) and in Semillon vines in Riverina (Holzapfel et al. 2006), both in Australia, where starch also declined, but several weeks after harvest. The differences in time between our findings and the Australian work reflect how the harvest date correlated with onset of leaf senescence and length of growing season. In Marlborough, leaf fall often occurs only a few weeks after harvest, while in the much warmer Australian wine regions, leaf fall is at least six weeks after harvest. However, in both regions, starch build-up ceases with canopy senescence.

Neither defoliation (Figure 7) nor node number (Figure 8) affected trunk starch, but both treatments affected root starch. Responses to postharvest defoliation treatments were observed mainly in the roots, expressed as a reduction in root starch by up to $50 \%$. In the trunk, only a $20 \%$ reduction in starch was found, but this happened simultaneously with an $\sim 40 \%$ increase in TSC. This supports the concept of the trunk as a transitional, accessible CHO reserve pool between the root system and the vine crown. It could be inferred that this is one

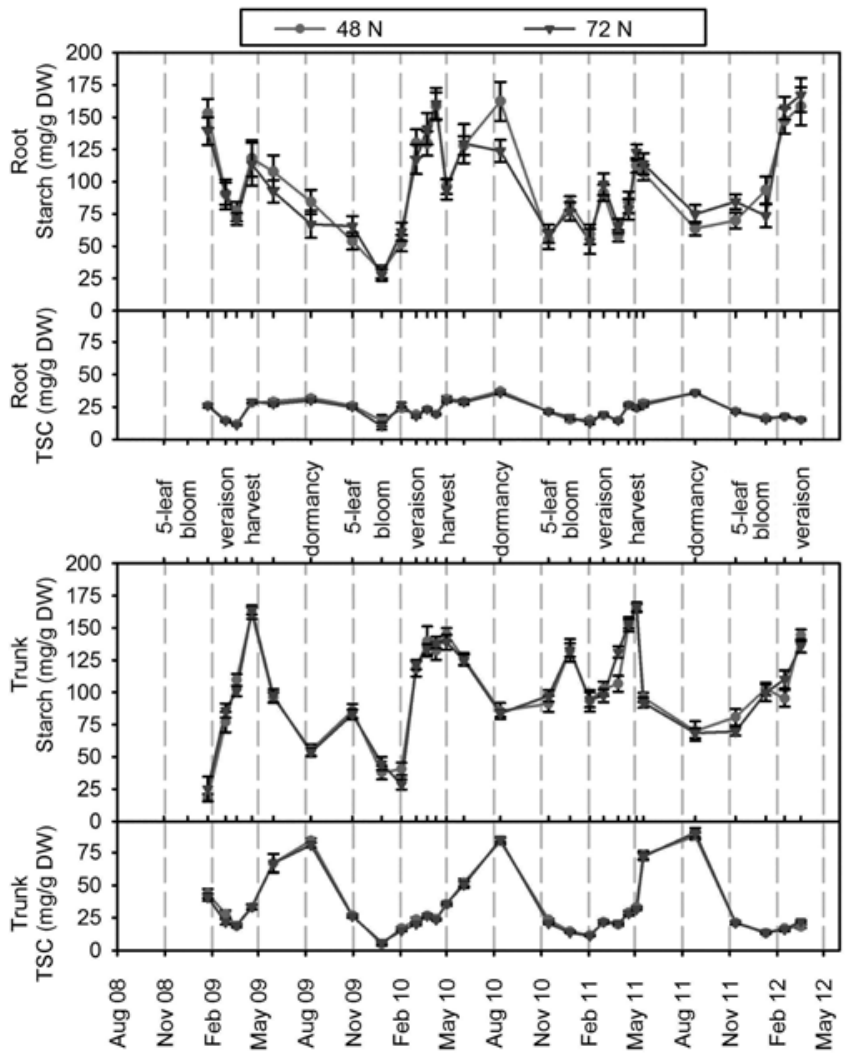

Figure 8 Total soluble carbohydrates (TSC) measured in root and trunk tissue from Sauvignon blanc grapevines with 48 or 72 nodes retained at pruning, with error bars indicating \pm SE. 
mechanism by which the vine responds to a major loss of leaf area (leaf defoliation): by remobilizing reserve $\mathrm{CHO}$ (starch) from the roots. However, the reduced root starch in response to defoliation, in addition to the reduced starch in root, but not in trunk, following a 50\% increase in retained nodes, suggest that the roots are probably the only true winter reserve pool, as found in Concord grape (Bates et al. 2002) and Pinot noir and Merlot (Zapata et al. 2004). The trunk may act as a transitional pool, although one with considerable quantitative capacity, suggesting a major role in buffering $\mathrm{CHO}$ supply within the whole vine. $\mathrm{CHO}$ is needed to harden off shoots for winter (Wample and Bary 1992). With sufficient time after harvest and a large enough leaf area, the required $\mathrm{CHO}$ can be produced by the photosynthetically active leaves. Early leaf drop or defoliation immediately after harvest reduces the leaf supply of $\mathrm{CHO}$ needed to harden off the shoots before winter. We suggest that this can be compensated for by stronger remobilization of reserve $\mathrm{CHO}$ in defoliated vines (Figures 7 and 8). Most of these carbohydrates are lost to the vine system, as most canes are pruned from the vines at winter pruning.

In the absence of leaves, inorganic $\mathrm{N}$ acquired postdefoliation or post-leaf fall (Figures 5 and 6 ) can be sequestered in root cell vacuoles or assimilated in the roots, using reserve $\mathrm{CHO}$ as a source of energy and carbon skeletons. $\mathrm{N}$ assimilation in roots is a costly process (Keller 2015) and is probably a major cause of the decreased root $\mathrm{CHO}$ observed between harvest and dormancy (Figures 7 and 8).

Although defoliation and increased node number reduced root starch significantly going into the winter period, all treatments reached a common minimum seasonal concentration around bloom. Non-defoliated treatments therefore potentially had quantitatively greater $\mathrm{CHO}$ reserves available for early development in the new season. Some vine responses reflected this, such as differences in blind bud proportions and changes in shoot number and size (Table 2). After three years, reduced yield and yield components were also found in defoliation and non-defoliation treatments (Table 2). No long-term depletion in $\mathrm{CHO}$ and $\mathrm{N}$ reserves occurred in response to combinations of pruning and defoliation; rather, the effects were expressed as reduced vine yields and vegetative growth.

The reduced starch in roots of $72 \mathrm{~N}$ vines at the start of the 2011 season (Figure 8) and the reduced shoot number, pruning weight, and cane weight induced by defoliation (Table 2) are examples of vine responses to altered carbon balance that affect ongoing vine productivity and fruit quality. Laying down $50 \%$ more nodes in the $72 \mathrm{~N}$ treatment created the potential to increase crop by 50\%. However, the extra crop load (yield) was achieved only in 2009, the first year of the treatment, and not in subsequent years, similar to reports by Greven et al. (2014).

In warm climates with long postharvest photosynthetic activity, $\mathrm{CHO}$ reserve buildup during that period can be considerable (Field et al. 2009, Holzapfel et al. 2006, Smith and Holzapfel 2009, Williams 1996). This work showed that, contrary to some suggestions (Bennett et al. 2005, Trought et al. 2011), even in cool climates, viticulture photosynthesis during the short postharvest period provides a valuable contribution to the vine reserve pool. In its absence, sustainable high yields may be hard to maintain. The present work suggests that leaving leaves on the vines for 10 days after harvest could be sufficient for a certain degree of nutrient retrieval into the vine reserves.

\section{Conclusions}

Changes in $\mathrm{CHO}$ and $\mathrm{N}$ reserves were both very dynamic and affected by different stages of vine development in response to defoliation and crop load differences. Defoliation or excessive crop load did influence $\mathrm{CHO}$ reserves in vines, but only after several consecutive years of treatments did lower yields and poorer vegetative growth occur. However, the reductions in trunk and root reserves could be replenished during the next seasonal growth cycle. This suggests that grapevine $\mathrm{N}$ and $\mathrm{CHO}$ partitioning favors the survival of vine permanent structure over increasing vine size or yield. Our work showed that even the short-lived postharvest canopy in cool climates contributes to the vine $\mathrm{CHO}$ pool.

In practical terms, the defoliation treatment as applied in this study can be equated to early leaf death caused by autumn frosts immediately postharvest. Where frost protection systems are installed, we recommend that postharvest frost protection should be carried out when vines are at risk of having low $\mathrm{CHO}$ reserves. This would include young vines, vines that have been carrying heavy crops, and vines that have suffered early leaf drop in previous years. The need for postharvest frost protection becomes increasingly important when vine reserves are depleted over several consecutive seasons, allowing the effects to accumulate.

\section{Literature Cited}

Bates TR, Dunst RM and Joy P. 2002. Seasonal dry matter, starch, and nutrient distribution in 'Concord' grapevine roots. HortScience 37:313-316

Bennett J, Jarvis P, Creasy GL and Trought MCT. 2005. Influence of defoliation on overwintering carbohydrate reserves, return bloom, and yield of mature Chardonnay grapevines. Am J Enol Vitic 56:386-393.

Bravdo B, Hepner Y, Loinger C, Cohen S and Tabacman H. 1985. Effect of crop level and crop load on growth, yield, must and wine composition, and quality of Cabernet Sauvignon. Am J Enol Vitic 36:125-131.

Candolfi-Vasconcelos MC and Koblet W. 1990. Yield, fruit quality, bud fertility and starch reserves of the wood as a function of leaf removal in Vitis vinifera- Evidence of compensation and stress recovering. Vitis 29:199-221.

Candolfi-Vasconcelos MC, Candolfi MP and Koblet W. 1994a. Retranslocation of carbon reserves from the woody storage tissues into the fruit as a response to defoliation stress during the ripening period in Vitis vinifera L. Planta 192:567-573.

Candolfi-Vasconcelos MC, Koblet W, Howell GS and Zweifel W. 1994b. Influence of defoliation, rootstock, training system, and leaf position on gas exchange of Pinot noir grapevines. Am J Enol Vitic 45:173-180.

Cheng L, Ma F and Ranwala D. 2004. Nitrogen storage and its interaction with carbohydrates of young apple trees in response to nitrogen supply. Tree Physiol 24:91-98.

Conradie WJ. 1986. Utilisation of nitrogen by the grapevine as affected by time of application and soil type. S Afr J Enol Vitic 7:76-83.

Conradie WJ and Bonnardot V. 2005. Effects of soil and climate on wine style in the Breede River Valley of South Africa: Sauvignon blanc and Cabernet Sauvignon. S Afr J Enol Vitic 26:33.

Coombe BG. 1995. Grape Phenology. In Viticulture. Volume 1. Resources. BG Coombe and PR Dry (eds.), pp. 139-153. Winetitles, Adelaide. 
Eltom M, Winefield CS and Trought MCT. 2014. Effect of pruning system, cane size and season on inflorescence primordia initiation and inflorescence architecture of Vitis vinifera L. Sauvignon Blanc. Aust J Grape Wine Res 20:459-464.

Field SK, Smith JP, Holzapfel BP, Hardie WP and Neil Emery RJ. 2009. Grapevine response to soil temperature: Xylem cytokinins and carbohydrate reserve mobilization from budbreak to anthesis. Am J Enol Vitic 60:164-172.

Gladstones JS. 1992. Viticulture and Environment. Winetitles, Underdale, Australia.

Greven MM, Green S, Neal S, Clothier B, Neal M, Dryden G and Davidson P. 2005. Regulated Deficit Irrigation (RDI) to save water and improve Sauvignon Blanc quality? Water Sci Technol 51:9-17.

Greven MM, Bennett JS and Neal SM. 2014. Influence of retained node number on Sauvignon blanc grapevine vegetative growth and yield. Aust J Grape Wine Res 20:263-271.

Greven MM, Neal SM, Hall AJ and Bennett JS. 2015. Influence of retained node number on Sauvignon blanc grapevine phenology in cool climate. Aust J Grape Wine Res 21:290-301.

Hamman RA, Dami IE, Walsh TM and Stushnoff C. 1996. Seasonal carbohydrate changes and cold hardiness of Chardonnay and Riesling grapevines. Am J Enol Vitic 47:31-36.

Holzapfel BP, Smith JP, Mandel RM and Keller M. 2006. Manipulating the postharvest period and its impact on vine productivity of Semillon grapevines. Am J Enol Vitic 57:148-157.

Howell GS. 2001. Sustainable grape productivity and the growth-yield relationship: A review. Am J Enol Vitic 52:165-174.

Jones KS, Paroschy J, McKersie BD and Bowley SR. 1999. Carbohydrate composition and freezing tolerance of canes and buds in Vitis vinifera. J Plant Physiol 155:101-106.

Keller M. 2010. Managing grapevines to optimise fruit development in a challenging environment: A climate change primer for viticulturists. Aust J Grape Wine Res 16:56-69.

Keller M. 2015. The Science of Grapevines: Anatomy and Physiology. $2 \mathrm{~d}$ ed. Academic Press, Cambridge, MA.

Kliewer WM and Antcliff AJ. 1970. Influence of defoliation, leaf darkening, and cluster shading on the growth and composition of Sultana grapes. Am J Enol Vitic 21:26-36.

Kozlowski TT and Pallardy SG (eds.). 1997. Physiology of Woody Plants. 2d ed. Academic Press, Cambridge, MA.

Loescher WH, McCamant T and Keller JD. 1990. Carbohydrate reserves, translocation, and storage in woody plant roots. HortScience $25: 274-281$

Löhnertz O, Schaller K and Mengel K. 1989. Nährstoffdynamik in Reben. III. Mitteilung: Stickstoffkonzentration und verlauf der aufnahme in der vegetation. Vitic Enol Sci 44:192-204.

Mullins MG, Bouquet A and Williams LE. 1992. Biology of the Grapevine. 1s ed. Cambridge University Press, Cambridge.

Peacock WL, Christensen LP and Broadbent FE. 1989. Uptake, storage, and utilization of soil-applied nitrogen by Thompson Seedless as affected by time of application. Am J Enol Vitic 40:16-20.

Petrie PR, Trought MCT and Howell GS. 2000. Influence of leaf ageing, leaf area and crop load on photosynthesis, stomatal conductance and senescence of grapevine (Vitis vinifera L. cv. Pinot noir) leaves. Vitis 39:31-36

Poni S, Casalini L, Bernizzoni F, Civardi S and Intrieri C. 2006. Effects of early defoliation on shoot photosynthesis, yield components, and grape composition. Am J Enol Vitic 57:397-407.

Ravaz L. 1903. Sur la brunissure de la vigne. Com Ren Acad Sci 136:1276-1278

Scholefield PB, Neales TF and May P. 1978. Carbon balance of the Sultana vine (Vitis vinifera L.) and the effects of autumn defoliation by harvest-pruning. Aust J Plant Physiol 5:561-570.

Sepúlveda G and Kliewer WM. 1986. Effect of high temperature on grapevines (Vitis vinifera L.). II. Distribution of soluble sugars. Am J Enol Vitic 37:20-25.

Smith GS, Clark CJ and Boldingh HL. 1992. Seasonal accumulation of starch by components of the kiwifruit vine. Ann Bot 70:19-25.

Smith JP and Holzapfel BP. 2009. Cumulative responses of Semillon grapevines to late season perturbation of carbohydrate reserve status. Am J Enol Vitic 60:461-470.

Stoev KD, Dobreva SI and Wosteninez G. 1966. On the synthesis of amino acids in rooting systems of grapevines. Vitis 5:265-287.

Tonietto J and Carbonneau A. 2004. A multicriteria climatic classification system for grape-growing regions worldwide. Agric For Meteorol 124:81-97.

Trought MCT, Bennett JS and Boldingh HL. 2011. Influence of retained cane number and pruning time on grapevine yield components, fruit composition and vine phenology of Sauvignon Blanc vines. Aust J Grape Wine Res 17:258-262.

Uys DC and Orffer CJ. 1983. Changes in carbohydrates in nurserygrown grapevine rootstocks. S Afr J Enol Vitic 4:13-19.

Wample RL and Bary A. 1992. Harvest date as a factor in carbohydrate storage and cold hardiness of Cabernet Sauvignon grapevines. J Am Soc Hortic Sci 117:32-36.

Weyand KM and Schultz HR. 2006. Long-term dynamics of nitrogen and carbohydrate reserves in woody parts of minimally and severely pruned Riesling vines in a cool climate. Am J Enol Vitic 57:172-182.

Williams LE 1996. Grape. In Photoassimilate Distribution in Plants and Crop Source-sink Relationships. E Zamski and AA Schaffer (eds.), pp. 851-881. Marcel Dekker Inc., New York

Williams LE and Smith RJ. 1985. Net $\mathrm{CO}_{2}$ assimilation rate and nitrogen content of grape leaves subsequent to fruit harvest. J Am Soc Hortic Sci 110:846-850.

Winkler AJ and Williams WO. 1938. Carbohydrate metabolism of Vitis vinifera: Hemicellulose. Plant Physiol 13:381-390.

Winkler AJ and Williams WO. 1945. Starch and sugars of Vitis vinifera. Plant Physiol 20:412-432.

Yang YS and Hori Y. 1979. Studies on retranslocation of accumulated assimilates in 'Delaware' grapevines. I. Retranslocation of 14Cassimilates in the following spring after $14 \mathrm{C}$ feeding in summer and autumn. Tohoku J Agric Res 30:43-56.

Zapata C, Deléens E, Chaillou S and Magné C. 2004. Partitioning and mobilization of starch and $\mathrm{N}$ reserves in grapevine (Vitis vinifera L.). J Plant Physiol 161:1031-1040. 